\title{
The Challenges and Strategies in Teaching TOEFL and IELTS Test Preparation
}

\author{
Delvia Roza \\ Universitas Islam Riau \\ email: delviaroza200785@gmail.com
}

\begin{abstract}
High-stake English proficiency tests, such as TOEFL and IELTS, open up opportunities for the people in Indonesia to study in reputable universities, both local and abroad. Since Indonesian learners are non-native English speakers, some institutions help them to overcome the problems they have with the tests. Related to these issues, the teachers may face some challenges in teaching the students who want to reach their target scores. For that reason, this study was conducted to find out: 1) teacher challenges in teaching the TOEFL and IELTS tests, and 2) teacher strategies in motivating the students. The location of the study was in an English educational institution in Pekanbaru. The participants were 10 teachers who had taught these tests preparation for more than two years. The method used was a qualitative approach with face-to-face interviews as the data collection instrument. It was found that the challenges of the teachers in teaching the tests were 1) students' high expectations, 2) lack of effort from students, 3) study time limitations, 4) teachers' experience, 5) issues with high school students, and 6) the number of students in a class. It was also found that the teachers' strategies in motivating the students were 1) students' awareness of the opportunities of passing the tests, 2) fun learning, 3) telling stories of people who are successful through passing the tests, and 4) reminding the students why they joined the class, spending much money, time and energy on these tests. All in all, though teachers faced some challenges in teaching IELTS and TOEFL tests, they also had strategies to overcome them.
\end{abstract}

Keywords: Teachers, Challenges, Strategies

\begin{abstract}
Abstrak
Tes kemampuan Bahasa inggris tingkat tinggi, seperti TOEFL dan IELTS membuka kesempatan kepada masyarakat di Indonesia untuk belajar di universitas yang bereputasi, baik universitas lokal maupun di luar negeri. Karena Bahasa Inggris bukan lah Bahasa asli dari para pelajar Indonesia, beberapa institusi membantu dalam mengatasi masalah mereka dalam menghadapi tes-tes tersebut. Berkaitan dengan hal-hal tersebut, para guru kemungkinan menghadapi beberapa tantangan dalam mengajar para siswa yang ingin mencapai skor target mereka. Oleh karena itu, penelitian ini bertujuan untuk mencari tahu: 1) tantangan-tantangan yang dihadapi para guru dalam mengajarkan persiapan tes-tes TOEFL dan IELTS, dan 2) strategi-strategi para guru dalam memotivasi para siswa. Lokasi penelitian ini adalah di salah satu institusi Pendidikan Bahasa Inggris di Pekanbaru. Para partisipan adalah 10 orang guru yang telah mengajar persiapan tes-tes tersebut selama lebih dari dua tahun. Metode penelitian yang digunakan adalah pendekatan Kualitatif dengan menggunakan wawancara tatap muka sebagai instrument pengoleksian data. Hasil penelitian menemukan bahwa tantangan-tantangan yang dihadapi oleh para guru adalah 1) ekspektasi para siswa yang tinggi, 2) kurangnya usaha belajar dari para siswa, 3) keterbatasan waktu belajar, 4) pengalaman para guru, 5) masalah-masalah yang berkaitan dengan murid-murid SMA, dan 6) jumlah siswa di dalam kelas. Kemudian, ditemukan bahwa strategi-strategi
\end{abstract}


para guru dalam memotivasi para siswa adalah 1) kesadaran para siswa akan kesempatan jika lulus pada tes-tes tersebut, 2) fun learning, 3) menceritakan sejarah orang-orang yang telah sukses dalam melewati tes-tes tersebut, dan 4) mengingatkan para siswa tentang mengapa mereka bergabung dalam kelas persiapan tes dengan menghabiskan banyak uang, waktu dan tenaga. Dapat disimpulkan bahwa walaupun para guru menghadapi beberapa tantangan dalam mengajar tes TOEFL dan IELTS, mereka mempunyai strategi untuk mengatasinya.

\section{Kata Kunci: Guru, Tantangan, Strategi}

\section{INTRODUCTION}

TOEFL (Test of English as a Foreign Language-Institutional TOEFL Prediction) and IELTS (International English Language Testing System) tests are English proficiency tests which measure the skills or ability of non-native English speakers. The tests are used for some purposes. In Indonesia, these tests are required in some institutions, such as universities, government institutions or international companies. They become entry requirements in some universities because English is the main language spoken throughout the teaching and the textbooks used during the study are in English, and those universities count as the best and most prestigious universities in Indonesia, as well as in the world, with sought-after majors like medicine, engineering, and international social science. Nurhayati and Giri (2015) stated that TOEFL and IELTS have now become the trend in the academic world and that they have also become the requirements for admission and graduation of universities. Erfani (2012) also agrees that TOEFL and IELTS are mostly used in academic settings, they are taken by researchers, teachers, students in higher education and employees.

Furthermore, TOEFL and IELTS can be a placement test for an English language program, a means of progress monitoring, a necessity for admissions to non-degree or short-term programs, admissions to universities in which English is not the dominant language, and a university exit test (Educational Testing Service, 2017; IELTS, 2017). The University Al Azhar Indonesia is an example of a university in Indonesia which requires TOEFL in its Academic Guideline Book 2009-2010. The university students are not allowed to graduate unless they have reached 450 of TOEFL PBT (Herwandar, Haryono and Safryono., 2012). Ananda (2016) supports this, stating that most prestigious universities in Indonesia require TOEFL and IELTS as the major requirements for admission, and they urge the students, both undergraduate and postgraduate, to obtain high scores for graduation.

TOEFL and IELTS are also requirements to apply for scholarships for students who want to continue their study in either Indonesia or abroad. Scholarships such as the Australia Awards Scholarship (AAS), USAID (the United States Agency for International Development) Prestasi, LPDP (Indonesia Endowment Fund for Education) oblige the applicants to have English language proficiency, so they can send the applicants to school abroad. Because of these reasons, it can be understood that English language proficiency tests are important to pursue a career and earn a university degree.

Despite their use as a requirement for university entry and scholarship, TOEFL and IELTS are viewed as the factors of international recognition rather than as an assessment of one's ability in communication (Khan, 2009). It is because 
those tests are biased towards the inner circle countries such as the UK, USA, Australia and Canada, they are not appropriate in the local context. Hence, the non-native English speakers find it quite difficult to comprehend the discourse and written text in both the TOEFL and IELTS tests.

In the TOEFL and IELTS tests, the skills tested are listening, reading, speaking and writing. TOEFL IBT is done in 4 hours and IELTS must be finished within 2 hours and 45 minutes. In consequence, it needs time management to finish the tests. That situation could create anxiety in the students or test takers when dealing with the problems of the TOEFL and IELTS tests.

For those reasons, some education institutions in Pekanbaru create a TOEFL and IELTS preparation course in order for the students to have the opportunity to achieve their desired scores. Besides, test preparation can reduce the test takers' anxiety and improve their motivation and confidence whatever their level of English proficiency. Therefore, a successful test preparation is needed to improve the learners' English language proficiency tests (Ward, 1998). Some studies also state that learners well-prepared in dealing with English language proficiency tests will improve their overall academic performance (Cho \& Bridgeman, 2012; Fakeye \& Ogunsiji, 2009; Feast, 2002). Moreover, taking English language proficiency tests without preparation will waste time and money (Al-Rawashdeh, 2010; Khodadadi and Yazdanmehr, 2009; Suryaningsih, 2014). Thus, English learners should take time to prepare by studying for the test in order to improve their performance.

Since the demand for English proficiency tests, in this case TOEFL and
IELTS, is high, so is the demand for the preparation course. In private educational institutions, some eligible teachers are hired to fulfil the test takers' needs. While teaching the students with diverse backgrounds, ages, jobs, preferences and demands, they possibly encounter some challenges.

Ball and Forzani (2009) found that challenges in teaching could be due to an inadequate background in teaching practice and an inability to adapt to the students and the contexts in which they will work. Saif (2006) stated that teachers must understand the process of the test development due to their responsibility during the teaching process. TOEFL and IELTS were such hard works for the students and it needed fun and creative learning from the teachers. Therefore, teachers must use improvisation and numbers of other interesting techniques to enliven the class.

Herreid (2006) argued that the large number of students could also be one of the problems in the classroom. The advantages of teaching many students could be cost effective and time saving since the materials are delivered at the same time. However, Herreid (2006) also claimed that the problems of having a large number of students are that the classroom is dominated by the small number of students who are interested in the subject being taught; that the number of students is too many; that it needs a large classroom which causes a difficulty for the teachers in hearing the students speak and vice versa. Herreid (2006) added that the problems of having many students in the classroom are attendance, discipline, learning and alienation of particular students. In brief, a large number of students may cause a lack of motivation of teachers in teaching and the same thing may also affect the 
motivation of teachers in teaching test preparation.

Due to the problems mentioned above, this states the research aims, which are to investigate issues related to teachers in teaching this high-stake English proficiency test preparation. The issues raise the following research questions:

1) What challenges do the teachers face in teaching English proficiency test preparation?

2) What strategies do the teachers use to motivate students in the teaching and learning process in dealing with the English proficiency test preparation?

\section{METHOD}

\subsection{Qualitative Approach}

In order to answer the research questions, this study employed a qualitative method of research. Bryman (2016) defines qualitative research as a research which emphasizes words rather than numbers in the data collection and analysis. Flick (2015) also states that qualitative research is not related to the model of a measurement as it is in quantitative research. In other words, qualitative research means developing more theories instead of counting or quantifying data.

Qualitative research helps by finding out the truth or perspectives of the academic staff, leaders and outside clients as a portrayal of the processes in a situation. They can be involved as individuals to share their experiences and views from their particular life situation (Flick, 2014). Moreover, the participant is free to specify what is relevant to them. Bernard (2017) argued that in qualitative research the respondent can be chosen precisely, so the researcher can collect the data based on what they need to figure out. For those reasons, qualitative research is considered to be the appropriate way in conducting this research. In addition, the purpose of undertaking a qualitative study is to be concerned with the understanding of the social occurrence from the teachers' point of view, through their experiences. In relation to that, the researcher can obtain the perspectives of teachers in teaching TOEFL and IELTS test preparation. Moreover, the phenomenon of interest in TOEFL and IELTS requires the interpretation and exploration of what teachers describe, state and view (Creswell, 2014; Patton, 1990 cited in Abrar and Mukminin, 2016; Merriam, 1998; 2016).

\subsection{Face-to-face interview}

Regarding the accessibility of the participants in this study, the researcher employed these face-to-face interviews. Braun and Clark (2011) stated that face-toface interviews are time-consuming for the researcher in doing the preparation, organization, conducting and transcribing, but they are flexible, ideal for sensitive issues, accessible, have smaller samples and rich, detailed data, and that the researcher has control over the data.

In preparing the interview, the researcher designed an interview schedule or interview guide (see Appendix), as it is commonly called. A good interview guide will build the trust of the participants, so that they will be comfortable in following the interview process (Braun \& Clarke, 2011).

Since qualitative research focuses on the responses of the participants, it is important to record the interview completely. Nowadays, audio recording devices are digital, ranging from basic MP3s to professional-level devices. The benefit of using recording in collecting the data is that the researcher can have a copy of the obtained data, and the audio recorder can be taken to the location where the researcher 
wants to hold the interview (Mathews \& Ross, 2010).

The next step after recording the interview is converting the data into transcriptions (Flick, 2015). Transcribing recorded data is a time-consuming activity since a one-hour interview can take five or six hours to transcribe (Matthews \& Ross, 2010). Nevertheless, in this study, the researcher used an audio recorder to collect the data and transcribed them as they were the convenient ways to obtain the findings.

\subsection{Participants}

The researcher employed purposive sampling in choosing the participants in this research. Purposive sampling is an approach to select sample on the basis of knowledge of a population, its elements and the objectives of study (Babbie, 2013). According to Cresswell (2007), purposive sampling can inform objectively in understanding the research problems by selecting the participants and sites of the study. Purposive samples are also accessible to people who have knowledge about specific matters, probably because of the predominance of their professional role, power, networking access, expertise or experience (Ball, 1990 as cited in Cohen et al., 2013).

The proposed participants of the study were the TOEFL and IELTS teachers who work in a private educational institution which specializes in TOEFL and IELTS preparation course. The participants were Indonesian with Bahasa Indonesia as their first language and who had been teaching TOEFL and IELTS for more than two years. The teachers who worked for this amount of time were believed to have enough experience to give responses on the issues. In the following table, the profiles of the proposed participants whose names were pseudonym zed are given.
Table 1. Participants' profiles

\begin{tabular}{|l|l|l|l|}
\hline No & Name & $\begin{array}{l}\text { Years' } \\
\text { Experience }\end{array}$ & Speciality \\
\hline 1 & Uya & 9 & TOEFL \\
\hline 2 & Kizara & 5 & TOEFL \& IELTS \\
\hline 3 & Seiza & 4 & IELTS \\
\hline 4 & Ahmad & 5 & TOEFL \& IELTS \\
\hline 5 & Zali & 3 & TOEFL \& IELTS \\
\hline 6 & Sani & 5 & TOEFL \& IELTS \\
\hline 7 & Mipah & 7 & TOEFL \\
\hline 8 & Nira & 14 & TOEFL \& IELTS \\
\hline 9 & Kizri & 3 & TOEFL \& IELTS \\
\hline 10 & Diyu & 15 & TOEFL \& IELTS \\
\hline
\end{tabular}

\subsection{Ethic}

In a study, the research participants have the right to be informed about the research and to withdraw at any time. Informed consent also requires that the research will not harm the participants nor reveal their identity (Flick, 2014). Matthews \& Ross (2010) explain that the consent form must be freely given to the participants, it should be clear with adequate information about the research, and the participants must be able to give their consent. For instance, if the research is dealing with children, parents will give the consent by proxy, on behalf of them.

To avoid harm to participants in collecting data, a researcher can use anonymization, which means that the names of the participants will not be mentioned in the study (Flick, 2014). Since the research findings will be disseminated, the participants can make it a consideration for taking part that they are assured that they are not identified, and anonymity is the best way. Another way to prevent the participants' names being mentioned is to use pseudonyms. A pseudonym is a fictional name given to replace the names 
of people, places or organizations to secure confidentiality, and researchers routinely use pseudonyms in order to broach sensitive topics (Given, 2008). By the use of pseudonyms, people will not recognize the names of participants nor research locations if the research findings are disseminated. However, care should be taken as the pseudonymized names could represent the characteristics of the participants (Given, 2008).

There were 10 teachers recruited in this research, and the approach used in securing a consent form from the teachers of the institution was by getting in touch with the director and asking permission to conduct the research there before getting in touch with the teachers and asking for their consent to be interviewed. The names of the teachers were pseudonymized, and any personal data of the institution and the teachers was secured in electronic form by using a password. Although the names of the participants were replaced by pseudonyms, the participants had the right to withdraw from the study at any time for any reason or none.

\subsection{Data Analysis}

After the data was turned into transcriptions, the researcher used a software called NVivo. NVivo is a piece of computer software commonly used in analysing qualitative data (Babbie, 2013, Bryman, 2016; Lewins and Silver, 2007; Matthews and Ross, 2010). Any forms of qualitative data such as transcripts, pictures, videos and audio materials can be exchanged into NVivo. Data imported to NVivo is changed into plain text (.txt), RTF (.rtf) and Microsoft Word (.doc), and the formats are editable within the software (Lewins \& Silver, 2007). Nonetheless, there was a time that the researcher used manual analysis in terms of the complexity of using the tools in completing the tasks. Also, a researcher should know the value of using manual and electric tools in analysing qualitative data (Welsh, 2002). However, manual analysis is still considered to be slow (Basit, 2003), and time-consuming.

\section{FINDING AND DISCUSSION}

In the interview, all participants shared their perceptions, points of view, feelings, opinions and experiences about teaching TOEFL and IELTS which is related to what Bernard (2017) is saying that the objective of a qualitative study is to focus on the teachers' perspectives through their experience in order to get a deeper understanding about the social situation. There were certain opposing views, but they were not significant since the participants were in the same field, so that the information they gave was similar. Additionally, some new phenomena were found during the process of data. collection. Thus, this introduces these phenomena and discusses them.

\subsection{Challenges of teachers in teaching TOEFL and IELTS}

\subsubsection{Students' high expectations}

Based on the information given by the participants, most of them agreed that the students' high expectations were one of the main challenges they faced during their teaching experience. Moreover, since the expectations of the students was followed by a lack of understanding of the English language, the teachers became very stressed. Al-Rawashdesh (2009) holds the view that a proper knowledge of English and a massive vocabulary will help when studying English proficiency test preparation. It means that the students should have had a basic knowledge of English before they started to study the test 
preparation. One teacher when discussing how she felt teaching the students who lacked ability stated:

"The challenges are the expectation of the students when they have a lower ability, but they hope to get higher scores. It's a little bit difficult for us to help achieve their expectations. It needs a lot of time..."

The other teachers also reinforced the point during the interviews. Most of them agreed that the expectation of the students was the biggest challenge of all. Diyu also added:

"The challenge... um... the students' expectation. They expect that they can get a high score in a very short time, while they don't have enough time to prepare."

Other comments also came from Sani who said that the students come with a really high expectation while their scores are not sufficient. For example, in TOEFL, the students get below 400, but expect to get a score of 500 or 550 . This expectation burdens her so much because it is difficult to achieve, since it takes time.

\subsubsection{Students' lack of effort}

The second challenge that the teachers faced was that the students with high expectations were students who made no effort. They, especially high school students, took the preparation class just to get the English proficiency tests certificate instantly. To confirm that, the teachers were interviewed about the attitude of the high school students and adults in the test preparation class, and the answer was that the students intended to get the certificate of the English proficiency tests otherwise they would not get their dream job and would not be admitted to their dream university. The high school pupils tended to be discouraged from studying while the adults tended to be serious about it. Due to this situation, a teacher commented:
"They (high school students) don't really have a strong motivation to study TOEFL. That's why, when I'm in class, they don't pay attention, you know, to what I'm teaching. So that's the challenge because senior high school students like playing, but at the same time they need a good score, they need the certificate to prepare them for university admission. But for adults, they want to get a job that needs the certificate, I think they are more serious."

Zali also said that some students who were lazy in studying the test preparations was caused by their parents who forced them. The parents wanted to send their children abroad for school or to get better jobs, but they were not interested doing one of those, so the students who came to study did not pay attention too much and did not do much effort to get better score.

All in all, the teachers who were responsible for the students held a huge challenge for both the students and parents.

\subsubsection{Study time limitation}

The limited time for the test preparation also caused problems in the test preparation. Most students came at the last minute to the test preparation class and they needed to improve their target score within two weeks. One teacher said:

"They expect they can get a higher score in a very short time while they don't have enough time to prepare. But, as you know, most of our students sometimes come at the last minute. They only have time for a month, even two weeks. And they want to have the (targeted) score in two weeks, and it is very challenging."

Another teacher, Uya also commented: "It (TOEFL) needs a lot of time since our course is kind of short course, only 16 meetings. Each meeting, we have 2 hours... if they got 450 (in their starting point/ pretest), it is uh... enough to get 500. But if 
their score is uh... about 300, it is difficult to get 500."

It can be concluded that students cannot come to the last minute to get their target score, especially when they have high score to reach.

\subsubsection{Teachers' experience}

The next problem is the experience of the teachers in teaching TOEFL and IELTS. Some of them admitted that they still have anxiety and lack of confidence in teaching TOEFL and IELTS even though they have taught them for more than 2 years and had qualifications to teach. The reason is the youngsters are getting smarter while the teachers were still guided by the books. Therefore, they needed to update their knowledge so that they could overcome their anxiety while teaching. It is related to what Ball \& Forzani (2009) said, that the teachers should overcome their anxiety in order to have a positive attitude toward teaching. As evidence, one of the teachers stated how she felt about teaching IELTS:

"The students that I have now, some of them are smarter than me, they are very, very... yeah... they have learned English since they were very young, and they use English when they speak with their friends, with their family, and they know much information, they have much general knowledge... I have to keep studying. I have to keep learning. I have to keep updating myself about the IELTS question tests."

Uya faced the same problems as she said that she needed to update herself with new vocabulary and test forms, so that she would not be left behind with the trend and would be more advanced than the students. Based on her experience, students who were smarter tended to underestimate their teachers and would not be motivated to study anymore.

\subsubsection{High school students' issues}

The other problem is when the students were high school students. Most of the teachers complained that high school students were noisy, not obedient and always distracted by their mobile phones. Kizara claimed, "High school students? Um... they are noisy. That's it." Ahmad also added, "High school students tend to follow their friends. Once their friends make a noise, they will do the same."

In contrast, Seiza mentioned that the high school students were disciplined, and they followed the rule and schedule. She remarked that adults tended to make excuses and be undisciplined.

\subsubsection{The number of students in the class}

The last problem is the number of students in the class. A large number of students will not be effective when delivering the TOEFL and IELTS test materials. As Herreid (2006) said, a large number of students in a classroom could be effective in time and money but not in attendance, discipline, learning and alienation of specific learners. One of the teachers, Kizri, shared his bad experience of having a large number of students. He said that he could not control the students and to make it worse, the students did not have good English skills, it made him frustrated. He said that it was easier for him to teach a small class consisting of 1 to 2 students, because he could motivate them. Nira also added that with a small number of students in a class, she can monitor their progress in studying the test preparation. 


\subsection{Strategies of Teachers in Motivating the Students in Test Preparation}

\subsubsection{Students' awareness}

Erfani (2014), Feast (2002) and Herwandar et al. (2012) justify TOEFL and IELTS being gained to meet the requirements of university admission and scholarships. It means that TOEFL and IELTS are important for those who need one of them. Job opportunities and good universities both local and abroad promise rewards for the people who want to reach them. That was one of the motivations that the teachers gave to the students in the teaching and learning activity. The teachers had a similar fundamental understanding that the students need TOEFL and IELTS for that reason. Six teachers agreed that they motivate the students by telling them that continuously. Uya told the students:

"If you want to get a scholarship, get a job, you need to go abroad, TOEFL and IELTS are important. (Because) some universities use TOEFL and IELTS as the entrance test."

In agreement with Uya, Kizri and Diyu also told the students that TOEFL and IELTS were very important if they wanted to take the advantages they brought.

Diyu: "Yeah, simple questions. Which one do you choose? Get the scholarship or miss it? Or if they need it for work, you want to get the job, or you will be jobless? So, it motivates them very much."

Kizri: "Some of them want to join the class because they want to take scholarships, and they know that TOEFL is important and I always remind them of that..."

To be concluded, since most teachers used this strategy, it worked to motivate the students to study the tests preparation.

\subsubsection{Fun learning}

For another strategy to motivate the students to study, Mipah suggested playing games after the students have finished studying the test preparation. He said that he needed to make the teaching and learning process interesting. He advised:

"... like I said, TOEFL and IELTS are such high standard tests of English. So, the students, if they don't have strong basic, they will get bored easily and they will get tired. And sometimes, I think, some of them said, "oh, my head will explode, sir, because of the difficult materials." So, I need to make the teaching and learning interesting. So, that's why sometimes we play game as well, even actually TOEFL needs to be serious, it's a serious subject, right? But we need to make it fun, so we sometimes play games."

Zali had her own strategy in making the learning condition fun. She said that she would do an approach like not to focus on textbook while teaching. She and the students would have some talks so that the burden the students had, especially those who were forced to study because of their parents' will, would disappear, and they would feel ease when studying

It means that to motivate the students in order to study, the teachers need to create games, fun activities and intermezzo in the classroom to overcome the boredom, monotony and seriousness of the teaching and learning process.

\subsubsection{Telling successful people stories}

Another way to motivate the students according to the teachers was telling of the people who gained their target score and what they did afterwards. Some teachers believed that this strategy could motivate the students in studying TOEFL and IELTS. They told histories based on their own experiences or the experiences of their 
friends and their students who had successfully achieved their target scores to enter their dream jobs or universities. The teachers used a similar strategy as it could raise the willingness of the students, especially high school students, to study. Some of the teachers stated:

Zali: "Sometimes, I motivate the students through the true stories of famous people, successful people or my own story or my friends' stories that the students can obviously see the advantages they have got by passing through the tests."

Ahmad: "At times, I tell the students about my friends who got scholarships and jobs. Many stories to tell to raise the advantages of these tests."

All in all, telling stories of people who were successful in reaching their target score would encourage the students to do the same thing. It could have been better if the story was from the teachers themselves so that the students could see by themselves and be motivated more as what Zali stated previously.

\subsubsection{Reminding students}

The next strategy to motivate the students was by reminding them why they joined the class. Since the test preparation class required much money, to remind them of such a thing was useful to increase the motivation of the students. Al-Rawashdeh (2010), Khodadadi \& Yazdanmehr (2009), and Suryaningsih (2014) hold the opinion that one of the challenges that the students have in studying TOEFL and IELTS is investing much energy, time and money in it. In relation to that, the students should keep on track. Nira commented about the students:

“... to get to their dream job, to get to their dream university, so I need to remind themselves, to remind them over and over again that TOEFL and IELTS are very important that they have to start studying about these for them to be prepared."

Kizri told the students how he reminded them about why they joined the class.

"What is the reason they join the class in the first place and other things maybe, I always remind them that this course is expensive, and you don't waste your time and money..."

From what is mentioned above, in a nutshell, asking the students in the beginning about what their targets were and what they intended to do with the score of TOEFL and IELTS could boost their motivation in studying for those tests.

\section{CONCLUSION}

From the findings obtained from the faceto-face interviews, it can be concluded that there were several challenges that the teachers encountered while teaching the high-stake English proficiency test preparation. In brief, the challenges faced by the teachers arose from the attitude of the students, the class situation and the anxiety of the teachers. However, most teachers agreed that the students' expectations to gain their target scores was the biggest challenge of all since that was the objective of the students in studying for the test preparation.

It was also found that there were some strategies that the teachers used in raising the motivation of the students in studying the test preparation. They told of the opportunities that the students might obtain if they gained their target scores; they played games with the students to reduce the monotonous situation in the classroom; they told of the people who gained their target scores and what they had done and experienced after that or they told the students the history of successful and 
famous people who had studied TOEFL and IELTS and they also kept reminding the students of the reasons why they signed up for the class and the money, time and energy they had expended on it.

The participants in this study gave their opinions and perspectives on the issues regarding the challenges and challenges in teaching test preparation. Following their responses, it was helpful to realize that new phenomena happened in the area of the study and many aspects need to be investigated more thoroughly. Overall, the findings show that the issues in the challenges and strategies of the teachers are clearly important concerns in the education world. Challenges encountered by teachers might affect feelings of frustration though the teachers had a strong motivation in teaching.

In order to develop and continue this research regarding the issues of the challenges and strategies of teachers in teaching High-Stake English proficiency tests, the following recommendations are suggested:

1. The findings came from a specific institution in Pekanbaru. It is suggested that further studies are sought in some educational institutions which provide the TOEFL and IELTS test preparation since TOEFL and IELTS are not included in the formal school curriculum. Nowadays, the need for TOEFL and IELTS tests is higher because of the many opportunities offered by many institutions, both state and private. Thus, some educational institutions might also offer test preparation to prepare the test takers to deal with the high-stake tests.

2. It is suggested that researchers find new phenomena in informal types of educational institutions and ask for the perspectives of the teachers, students and administration staff on likely phenomena which may happen in conducting the TOEFL and
IELTS test preparation; what problems can be foreseen which have not been exposed yet; what causes issues in carrying out the TOEFL and IELTS tests in the community; what issues may arise in carrying out the TOEFL and IELTS tests in a specific area; what locations or communities do not have opportunities to have TOEFL and IELTS but where the demand for the tests is great, and so forth.

3. The researcher suggests that future studies will discuss more about the development of materials and an applicable curriculum for TOEFL and IELTS test preparation so that the authors or publishers can create more practical and suitable books for English learners, especially the learners from non-native English speaking countries where English is approached as a foreign language.

4. It is also suggested that further studies will recruit a variety of participants, such as parents of elementary school pupils; middle school and high school students; administration staff of institutions where the TOEFL and IELTS tests are organized; university student admission staff and all related parties who are involved in the execution of TOEFL and IELTS tests. It will be interesting to know their point of view regarding the related issues of the tests. Moreover, a larger sample size could also be recruited since there are so many people interested in TOEFL and IELTS. In addition, the use of methods in data collection is advised to be varied in order that the findings of the data will be more reliable.

5. Finally, the researcher recommends that future studies will develop this study exploring it more in order that the related issues will be more perfectly understood. 


\section{REFERENCES}

Abrar, M., \& Mukminin, A. (2016). International Graduate Classroom Discussion Engagement, Challenges, and Solving-Strategies. Asia-Pacific Collaborative Education Journal, 12(1), 5-19.

Al-Rawashdeh, H. (2010). Difficulties that face graduate students during their TOEFL preparation program at Jordanian Universities. Abhath Al-Yarmouk Humanity and Social Science.

Babbie, E. 2013. The practice of social research 13th edition: International edition. Wadsworth Cengage Learning.

Ball, D., \& Forzani, F. M. (2009). The work of teaching and the challenge for teacher education. Journal of teacher education, 60(5), 497-511.

Braun, V., \& Clarke, V. (2011). Successful qualitative research: A practical guide for beginners. Sage.

Bryman, A. (2016). Social research methods. Oxford university press.

Cho, Y., \& Bridgeman, B. (2012). Relationship of TOEFL iBT® scores to academic performance: Some evidence from American universities. Language Testing, 29(3), 421-442.

Cohen, L., Manion, L., \& Morrison, K. (2013). Research methods in education. Routledge.

Creswell, J. W. (2014). Educational research: Planning, conducting, and evaluating quantitative and qualitative research. England: Pearson Education Limited.

Erfani, S. S. (2012). A comparative washback study of IELTS and TOEFL iBT on teaching and learning activities in preparation courses in the Iranian context. English Language Teaching, 5(8), 185.
Erfani, S. S. (2014). An Investigation on the Attitudes of IELTS and TOEFL iBT Teachers: A Quantitative and Qualitative Washback Study. British Journal of Education, Society \& Behavioural Science, 4(1), 88-102.

Educational Testing Service (ETS). (2017). About the TOEFL iBT® test. Available from https://www.ets.org/toefl/ibt/about [Accessed 08/03/2017].

Fakeye, D. O., \& Ogunsiji, Y. (2009). English language proficiency as a predictor of academic achievement among EFL students in Nigeria. European Journal of Scientific Research, 37(3), 490-495.

Feast, V. (2002). The impact of IELTS scores on performance at university. Doctoral dissertation. Flinders University.

Flick, U. (2014). An introduction to qualitative research edition 5. Sage.

Flick, U. (2015). Introducing research methodology: A beginner's guide to doing a research project. Sage.

Given, L. M. (Ed.). (2008). The Sage encyclopaedia of qualitative research methods. Sage Publications.

Herreid, C. F. (2006). " Clicker" Cases: Introducing Case Study Teaching into Large Classrooms. Journal of College Science Teaching, 36(2), 43.

Herwandar, R., Safryono, D. A., \& Haryono, P. Y. (2012). Evaluasi Program Matrikulasi" TOEFL" Mahasiswa Universitas Al Azhar Indonesia 2010/2011. SERI HUMANIORA, 1(3), 179-188.

IELTS. (2017). IELTS introduction. Available from https://www.ielts.org/what-is-ielts/ieltsintroduction [Accessed 08/03/2017].

Khan, S. Z. (2009). Imperialism of international tests: An EIL perspective. English as an international language: 
Perspectives and pedagogical issues, 190-205.

Khodadadi, E., \& Yazdanmehr, E. (2009). Learners' evaluation of EFL writing tasks in Iran's ESOL exam preparation courses. Journal of English Language Teaching and Learning, 1(212), 77-106.

Matsuoka, Y. (2009). Possible strategies for listening comprehension: Applying the concepts of conversational implicature and adjacency pairs to understand speaker intention in the TOEFL listening section. Accents Asia [Online], 3 (2), 27 56

Saif, S. (2006). Aiming for positive washback: A case study of international teaching assistants. Language Testing, 23(1), 1-34

Silver, C., \& Lewins, A. (2007). Using software in qualitative research: A stepby-step guide. Sage.

Suryaningsih, H. (2014). Students' perceptions of international English language testing system (IELTS) and test of English as a foreign language (TOEFL) tests. Doctoral dissertation: Indiana University of Pennsylvania.

Taylor, S. J., Bogdan, R., \& DeVault, M. (2015). Introduction to qualitative research methods: A guidebook and resource. John Wiley \& Sons.

Welsh, E. (2002). Dealing with data: Using NVivo in the qualitative data analysis process. In Forum Qualitative Sozialforschung/Forum: Qualitative Social Research (Vol. 3, No. 2).

\section{APPENDIX}

\section{Interview Guide}

1. How long have you been teaching English?

2. How long have you been teaching TOEFL and/or IELTS test preparation?
3. What test are you teaching? TOEFL? IELTS? Or both?

4. What language do you use in teaching TOEFL and/or IELTS test preparation?

5. What textbook(s) do you use in teaching TOEFL and/or IELTS?

6. What do you think the effectiveness of the textbook(s)?

7. What are the good parts in teaching TOEFL and/or IELTS test preparation?

8. What are challenges in teaching TOEFL and/or IELTS test preparation?

9. What are the differences between teaching general English and TOEFL and/or IELTS test preparation?

10. Are there any differences in teaching high school students and adults?

11. How do you motivate students in studying TOEFL or IELTS test preparation?

12. How do you motivate yourself in teaching TOEFL or IELTS test preparation? 13. What strategies do you use in teaching TOEFL or IELTS test preparation? 14. Do you use strategy(-ies) in any circumstances? If yes, what is/are the other(s)?

15. What teaching methods do you employ for general English class as opposed to test preparation classes?

16. What do you expect when teaching TOEFL or IELTS test preparation? Student's ability in English in general? Or student's desired score?

17. Do you think the students' scores improved after studying the test preparation?

18. What do you think helps people in learning English?

19. What do you think helps people to pass the tests?

20. What do you suggest for teachers who teach TOEFL and/or IELTS test preparation? 